\title{
Montenegro on the Path to Paris MoU Accession: Towards Achieving a Sustainable Shipping Industry
}

\author{
Jelena Nikcevic \\ Maritime Faculty, University of Montenegro, Dobrota 36, 85330 Kotor, Montenegro; jelenag@ac.me; \\ Tel.: +382-67-237-422
}

Received: 14 April 2018; Accepted: 31 May 2018; Published: 6 June 2018

\begin{abstract}
In order to ensure the sustainability of the shipping industry and marine ecosystem of Montenegro, it is necessary that Montenegro becomes a full member of the Paris Memorandum of Understanding (Paris MoU) on Port State Control. The reasons for doing so are numerous: the full adoption of standards stipulated by the Memorandum in relation to ship control; continuously keeping pace with, and development of, new standards in compliance with turbulent changes in the maritime industry and operation (including the increasing scope of maritime transport); the decrease in the number of detained ships which meet the requirements stipulated in international Conventions and the elimination of substandard ships in perspective; and the prevention of environmental pollution, and sea and port incidents. This justified endeavour is supported by the fact that Montenegro is one of two countries in Europe that are not full members of the Paris MoU. Additionally, in this context it is necessary to emphasise the fact that the marine ecosystem of Montenegro is an integral part of the world ocean. Accordingly, the improvement of the quality of national legislation which is compliant with international requirements is an imperative which has positive implications on regional and global sustainability.
\end{abstract}

Keywords: port state control; Paris MoU; Montenegrin accession; sustainable shipping

\section{Introduction}

The world ocean absorbs carbon-dioxide from the atmosphere, provides one half of the oxygen needed to the living world, and food for approximately three billion people across the globe. It abounds by other numerous resources used by people, regulates climate, and over $90 \%$ of the world transport, in terms of scope, and over $60 \%$ of transport, in terms of value, takes place by sea [1,2]. Throughout history, the sea has always played an extremely important role for mankind both as a space of communication and as an inexhaustible source of food, which has been evidenced by numerous historical sources [3]. Some countries link practically all their economic activity to the sea and marine resources. Throughout history, the sea has been the condicio sine qua non of the development of numerous civilizations and numerous wars waged in order to gain access to the sea. On the other hand, the world ocean has been exposed to numerous threats in terms of sustainability due to increasingly dramatic climate changes, deacidification of seas and oceans, an increase in the sea level, volatile catching of fish, and numerous natural and human-induced disasters. Human-induced disasters include, inter alia, problems related to so-called "substandard ships", i.e., ships which do not fulfill the standards stipulated by international Conventions, which sail by world oceans and frequently cause maritime accidents. Clearly, maritime accidents result in great losses for the shipping industry and overall society since they cause the loss of human lives, ships, cargo, and pollution of the marine ecosystem [4].

In order to ensure the sustainability of the world ocean, mankind should work on the prevention of these threats by acting proactively in all spheres of maritime affairs, including the legal framework 
toward the adoption of preventive regulations. It would be incorrect to say that the legislation in this field does not exist on a global basis. However, its full implementation in specific regions is delayed. This, in turn, requires the need for increased responsibility of countries in terms of a coordinated decrease of shipping environmental impact [5].

Finding of optimal legal solutions creates a favorable basis for the sustainability of the shipping industry and marine ecosystem in extremely dynamic present conditions [6]. The legislative framework necessitates positive changes which would accompany socio-economic needs and dynamics, while observing the principle of sustainability. Additionally, efforts should be made to develop inclusive strategies for the successful management of seas for today and the future.

The International Maritime Organisation (IMO), as the overarching organization which is in charge of, inter alia, protection of the sea against pollution, has adopted numerous international and regional regulations in this field [7]. Of particular importance are those regulations which put an emphasis on a sustainable shipping industry and inspection of faults in ships. The Paris Memorandum of Understanding, which is the focus of this work, is one such regional Agreement, i.e., a legal instrument for the identification and resolution of issues in the shipping industry, as well as the activities related to incidents which can negatively affect the marine ecosystem. A special focus of this work has been devoted to this Memorandum from the aspect of the necessity of ensuring full membership of Montenegro in the Memorandum in the recent future-Montenegro being one out of two countries in Europe which have still not become full members, thus causing a discontinuity in the insurance of a sustainable shipping industry on European and global scales.

The first part of the work provides a brief overview of the development of the legal framework of Montenegro in two segments, following its constitution as an independent state. One segment relates to navigation safety and the other relates to environmental protection, including the marine environment. Additionally, the work lists regional and international Conventions adopted by Montenegro in these fields. The second part of the work describes the Paris $\mathrm{MoU}$ in terms of its tasks and manner of functioning. The third part of the work is devoted to activities of Montenegro toward full membership, as well as to certain impediments and successes on this path. Finally, the work provides concluding considerations and guidelines for further research.

\section{Creation of Legislative Framework of Montenegro in the Function of a Sustainable Shipping Industry}

Following turbulent political changes of the territory of the former Yugoslavia [8], Montenegro recovered its statehood in 2006, established its legal system [9], and entered the international scene as an independent state and the subject of international law and obligations. The establishment of the new legislative framework implied quite complex legal reforms for Montenegro in all fields of society, with special reflection on maritime legislation, including the protection of the marine ecosystem and the insurance of sustainability.

In order to understand properly the maritime legislation of Montenegro which is in force at present, we provide below a brief overview of the legislation which existed in the past, while Montenegro was a part of the Socialist Federal Republic of Yugoslavia-(SFRY 29 November 1945-27 April 1992), then the Federal Republic of Yugoslavia (28 April 1992-4 February 2003) and, finally, the State Union of Serbia and Montenegro (4 February 2003-5 June 2006). This legal heritage had a significant influence on the creation of maritime legislation of Montenegro.

Forty years ago, the overall field of maritime law in the territory of the former Yugoslavia was systematised and codified by the Law on Maritime and Inland Navigation (LMIN) which was adopted in 1977 [10]. This Law, in qualitative and quantitative terms, exceeded the scope of "ordinary" laws. Given that this Law regulated the overall field of maritime law, it is clearly a very large legal text comprising 1078 Articles [11]. We can freely say that this was the most voluminous legal codifying act adopted in the territory of the former SFRY. In 1992, when SFRY dissolved, this Law was transposed in its totality to the legislation of the newly established Federal Republic of Yugoslavia [12]. This period 
was characterised by political unrest, which was largely reflected on the maritime-legal regulations. Namely, from 1992, due to the sanctions imposed by the international community and dissolution of the state, the Federal Republic of Yugoslavia did not keep pace with the development of international law. International conferences were not attended and, accordingly, no Convention in the field of maritime law was either signed or ratified during the period of sanctions. Although expert-scientific groups were set up with the task to update the LMIN, the task remained unfinished. Following this discontinuity caused by sanctions and civil war, the old-new LMIN [13] was adopted on 5 March 1998. However, it did not incorporate any update which was necessary despite the fact that certain international Conventions were adopted in the meantime.

Following the recovery of its statehood in 2006, Montenegro created its legislative framework in the field of maritime affairs as an independent and sovereign state. Pursuant to the Decision Promulgating Independence [14], Montenegro transposed into its national legislation the unmodified LMIN which was in force in the State Union of Serbia and Montenegro. The question which arose at the very beginning was how to regulate the subject of maritime law conceptually: to adopt a separate law on maritime navigation and a separate one on inland navigation, to make the existing LMIN compliant with conventions in those aspects where it was not harmonised, or to adopt new laws that conceptually differ from the existing LMIN while treating the differences noted in practice.

Unlike the former member states of Yugoslavia, Croatia and Slovenia, which started the development of a maritime-legal framework by separating maritime and inland navigation and adopted separate laws in these fields [15,16], Montenegro opted for a different approach. Namely, Montenegro became oriented to the adoption of several laws which separately regulate specific fields of maritime law. The provisions of the LMIN which related to the subject in question repealed with effect from the date of entry into force of separate laws. The reasons for such an approach of the Montenegrin legislature should certainly be traced to the excessive volume and extensive systematics of the LMIN and, then, the fact that the subject of maritime law had been regulated by separate pieces of legislation in many coastal states in the world. The reasons of a legal-technical nature should be added to this. More precisely, from the aspect of legal procedure, it is much easier to adopt and amend by-laws through which the adopted laws are implemented, than to adopt and amend the laws themselves.

In compliance with the above, Montenegro adopted the following laws: the Law of the Sea [17] and Law on Yachts [18] in 2007, the Law on Ports [19] in 2008, the Law on Marine Fisheries and Mariculture in 2009 [20], the Law on the Prevention of Sea Pollution from Vessels [21], the Law on Maritime Navigation Safety [22], and the last adopted Law on Safety Protection of Ships and Ports [23] in 2016.

\subsection{Montenegrin Legislation-De Lege Lata}

In the context of this work, of particular importance are the Law on Maritime Navigation Safety and the Law on the Prevention of Sea Pollution from Vessels as essential laws establishing the legal framework for safe navigation and ensuring prevention of sea pollution from vessels in the function of sustainability of the marine ecosystem of Montenegro. The Law on Maritime Navigation Safety regulates all segments of safety at sea (ship safety, cargo safety, occupational safety, and navigation safety) with the aim of ensuring the avoidance of maritime accidents and, in relation to this, pollution of the sea and marine ecosystem. Particularly important is Part XIV, entitled "Inspection" (Article 183 to 198), which regulates, inter alia, the performance of port state control of foreign ships and their fleets calling at the ports or anchorages of Montenegro by the Montenegrin Port State Control Officers (PSCO), with the view of protecting the sea and improving safety [22]. On the other hand, the Law on the Prevention of Sea Pollution from Vessels endeavours to prevent, decrease and, to the greatest possible extent, eliminate the pollution of the marine environment. The Law regulates the following: materials prohibited from being discharged into the sea from vessels; measures and communication procedures to be observed while ships enter and leave the ports of Montenegro; the construction, equipment, and conditions to be fulfilled by vessels; conditions and manner of packing of harmful 
and polluting substances; conditions and manner of discharging of sewage from ships; discharge of communal waste from ships; pollution of air from ships; ballast water (measures and procedures for their replacement, replacement control); manner of waste discharge into the sea and waste burying; waste reception and management; responsibility and compensation of damage, etc. [21]. In April 2011, Montenegro adopted the National Plan for Emergent Reaction in the Event of Sea Pollution from Vessels. This Plan specifies the manner of work and action, tasks and responsibilities, measures and procedures aimed at prevention, decrease, and remedy of consequences of sea pollution from vessels. The purpose of the Plan is to ensure a timely and efficient reaction to maritime accidents of sea pollution from vessels at the national level. The Plan applies in the event of a maritime accident which caused or may have caused pollution in the maritime areas, at the sea bed, or below the sea bed of Montenegro, which includes internal waters and the territorial sea [24]. Protection and preservation of the maritime environment have been regulated by other laws of the Montenegrin legislation. In this regard, particularly important are Article 2 and Article 19 paragraph 2 of the Law of the Sea [17], Article 26 paragraph 2 of the Law on Ports [19], and Articles 33 and 42 of the Law on Yachts [18].

In addition to the mentioned laws in the function of sustainable development of the shipping industry and marine ecosystem, it is important to mention the Law on Environment from 2008 [25] which set the grounds for implementation of environmental protection policy in Montenegro based on the principles of sustainable development. The laws which were implemented on the territory of the former Yugoslavia prior to this law include the following: the Federal Law on the Fundamentals of Environmental Protection from 1988 [26], the Republic Law on Environment from 1996 [27], and the Law on Nature Protection from 1977 [28]. These laws only dealt with protection of the marine environment.

After a multi-annual implementation of the Law on Environment from 2008, the need arose to amend the Law and to introduce the new, improved legal solutions. In 2016, Montenegro adopted the new Law on Environment which is, at the moment, an overarching law in this field [29]. This Law governs the principles of environmental protection and sustainable development, instruments, and measures aimed at environmental protection, and other issues of importance for the environment. Only a few articles of this law relate to the sea as a segment of the environment which has to be protected from pollution on a separate basis, but also along with other segments of environment, taking into consideration their mutual relations and mutual influence. The Law particularly emphasises that a marine ecosystem is a marine environment which has to be preserved and protected in order to maintain biodiversity and ensure the diversity and dynamism of the processes which take place in the seas and oceans. The novelty of the Law is Article 29 which stipulates the obligation to adopt the Strategy on Marine Environment Protection as one of the documents of sustainable development and environmental protection, i.e., marine environment protection. The strategy would define the principles, objectives, and measures for the accomplishment of a good environmental condition of marine environment and protection of its resources, and monitoring programme of the marine environment [29]. Up to date, such a strategy has not yet been adopted in Montenegro.

\subsection{Adopted International Conventions}

Clearly, the described chronology of the development of the legal framework of Montenegro is inextricably linked with the preceding harmonisation with international Conventions. In terms of international-legal regulation of safety at sea and protection of the marine environment, Montenegro ratified numerous Conventions which, pursuant to Article 9 of the Constitution of Montenegro, became an integral part of its internal legal order [30].

In terms of safety at sea, Montenegro is a signatory to the following Conventions: the International Convention on Safety of Life at Sea (SOLAS 1974) as amended, the Convention on Load Lines (LL convention, 1966), the International Convention on Tonnage Measurement of Ships (TONNAGE, 1969); the International Convention on Standards of Training, Certification, and Watch-keeping for Seafarers (STCW 1978) as amended, and the Maritime Labour Convention (MLC 2006) [31]. 
In terms of sea pollution, Montenegro is a signatory to the following Conventions: the UN Convention on the Law of the Sea (UNCLOS 1982); the International Convention relating to Intervention on the High Seas in Cases of Oil Pollution Casualties (INTERVENTION 1969); the Protocol to the International Convention relating to Intervention on the High Seas in Cases of Pollution by Substances other than Oil (INTERVENTION PROT 1973) as amended; the Convention on the Prevention of Marine Pollution by Dumping of Wastes and Other Matter (LC 1972) as amended; the International Convention for the Prevention of Pollution from Ships, 1973 (MARPOL, 1973) as modified by the Protocol of 1978 relating thereto, and its Annexes from I to VI (MARPOL 73/78); and the Convention concerning Minimum Standards in Merchant Ships, 1976.

In 2011, Montenegro ratified the following Treaties: the International Convention for the Control and Management of Ships' Ballast Water and Sediments, 2004.; the International Convention on the Control of Harmful Anti-fouling Systems on Ships, 2001; the International Convention on Civil Liability for Bunker Oil Pollution Damage, 2001; the International Convention on Civil Liability for Oil Pollution Damage, 1992.; the International Convention on the Establishment of an International Fund for Compensation for Oil Pollution Damage, 1992.; the Protocol of 2003 to the International Convention on the Establishment of an International Fund for Compensation for Oil Pollution Damage; and the International Convention on Liability and Compensation for Damage in connection with the Carriage of Hazardous and Noxious Substances by Sea, 1996 [31].

In addition to national and international legislation, regional cooperation, as a link between the above specified levels of legal regulations, is important in terms of navigation safety and protection of the marine environment. The advantage of the regional approach is that it takes into account the specificities of certain marine areas and the possibility of adjustment to the problems of a specific region and coordinated action, toward the accomplishment of objectives of common interest [32-36]. The ratification of the Paris MoU, as one of regional Agreements whose objective is, among other things, protection of the marine environment, is particularly important for Montenegro [37].

In the next part of the work, a special emphasis will be given to the Paris MoU and justified endeavours of Montenegro to become a full member of this regional alliance.

\section{Paris MoU}

In order to increase safety at sea, protect the marine environment, and improve working and living conditions of crews, The Paris MoU was adopted and signed in Paris on 26 January 1982. Its adoption was preceded by the accident of the ship Amoco Cadiz that occurred in March 1978 [4]. This accident drew great political and public attention in Europe toward the introduction of stricter rules related to maritime navigation safety and prevention of sea pollution from vessels.

The representatives of the International Maritime Organisation (IMO), International Labour Organisation (ILO), European Commission, and 14 ministers in charge of maritime safety agreed that the adoption of a legal instrument in the form of a regional Agreement on Cooperation of maritime administrations in the field of port state control (PSC) would greatly contribute to navigation safety.

\subsection{Concept}

The concept of the Paris MoU is to ensure a unified and harmonised implementation of law on ship control through the establishment of a harmonised system of ship control. This system is to control whether, and to what extent, the ships calling at the ports of the MoU region observe the existing international rules and standards. The ultimate objective of controls is to completely eliminate from ports those ships which do not meet the stipulated standards (substandard ships), thus ensuring navigation safety and marine environment protection [36,38-40]. In other words, it is essential to identify the ships that pose a great risk to navigation (of the Paris MoU region) and undertake certain corrective measures before permitting such ships to continue navigation.

Although the Paris MoU is the earliest regional Agreement on Port State Control, this type of control is not new and was not first introduced by the MoU. Instead, it has been envisaged by 
numerous existing international Conventions [41]. The generally-adopted attitude is that the need for the establishment of PSC would not exist if the flag states behaved in a responsible manner to their ships and observed their commitments envisaged by international Conventions [35,42]. Given that the mechanisms of the control of flag state ships, classification entities, and other participants in the chain of maritime safety turned out to be inefficient in practice in terms of the struggle against substandard ships, the active participation of port states in the control of foreign ships seemed inevitable [43,44].

The implementation of the Paris MoU started on 1 July 1982, when it entered into force. Since its entry into force, the number of Signatory States (State Parties) increased from 14 to 27. Nowadays, it includes almost all costal states of Europe (excluding Montenegro and Albania), as well as Canada and Russia, which geographically belong to the North Atlantic basin. Having been the first regional Agreement, it was a model based on which the other regions of the world adopted their own Agreements [33,34,41,45]. In addition to the Paris MoU, there have been another eight regional Agreements around the world, at present, which regulate port state control, including the Latin American Agreement 1992; Tokyo MOU, 1993; Caribbean MOU, 1996.; Mediterranean MOU 1997; Indian Ocean MOU, 1998; Abuja MOU, 1999; Black Sea MOU, 2000; and Riyadh MOU, 2004. The most dynamic and ongoing of these regimes are the Paris MoU and Tokyo MoU. In May 2017, a joint ministerial conference of the Paris and Tokyo MoU was held in Vancouver, Canada. The significance of this conference is the reiteration of members' commitment to eliminate substandard shipping, protect the global navigational environment, and safeguard working and living conditions for all seafarers $[46,47]$.

In order to meet the requirements of safety and protection of the marine environment stipulated by IMO and ILO instruments and EU legislation to the greatest possible extent, the text of the Paris MoU has been improved by introducing numerous amendments. In this sense, the consolidated version of the Paris MoU (nine Sections and 12 supporting Annexes) which entered into force on 1 July 2017 and which, at present, includes 40 Amendments currently applies [48].

The Paris MoU does not introduce new rules or standards (requirements) to be met by ships. Instead, it establishes inspection (control) over the application of the existing safety standards contained in numerous international Conventions, i.e., "relevant instruments", as termed by the MoU, adopted by the IMO and ILO [41,49,50]. Section 2.1, Article 2 of the Paris MoU [48] provides a list of 17 "relevant instruments": The International Convention on Load Lines, 1966; the Protocol of 1988 relating to the International Convention on Load Lines, 1966 (LL PROT 88); the International Convention for the Safety of Life at Sea, 1974; the Protocol of 1978 relating to the International Convention for the Safety of Life at Sea, 1974; the Protocol of 1988 relating to the International Convention for the Safety of Life at Sea, 1974; the International Convention for the Prevention of Pollution from Ships, 1973, as modified by the Protocol of 1978 relating thereto, and as further amended by the Protocol of 1997; the International Convention on Standards of Training, Certification and Watchkeeping for Seafarers, 1978; the Convention on the International Regulations for Preventing Collisions at Sea, 1972 (COLREG 72); the International Convention on Tonnage Measurement of Ships, 1969 (TONNAGE 69); the Merchant Shipping (Minimum Standards) Convention, 1976 (ILO Convention No. 147); the Protocol of 1996 to the Merchant Shipping (Minimum Standards) Convention, 1976 (ILO Convention No. 147); the Maritime Labour Convention, 2006; the International Convention on Civil Liability for Oil Pollution Damage, 1969 (CLC1969); the Protocol of 1992 to amend the International Convention on Civil Liability for Oil Pollution Damage, 1969 (CLC PROT 1992); the International Convention on the Control of Harmful Anti-Fouling Systems on Ships, 2001 (AFS2001); the International Convention on Civil Liability for Bunker Oil Pollution Damage, 2001; and the International Convention for the Control and Management of Ships' Ballast Water and Sediments, 2004. (BWM).

The listed IMO and ILO "relevant instruments" create the basis for the performance of inspections, and the maritime authorities of Signatory States are bound to apply them (Section 2 under Sections 2.2 and 2.3) [48]. Additionally, ships entitled to fly the flag of a State which is not 
a Party to a "relevant instrument" will not have a more favourable treatment ("no more favourable treatment"). Such ships will not be exempted from inspection. Instead, the same procedures will apply to them as those stipulated for ships to which "relevant instruments" apply. In the case of ships below Convention size, the Paris MoU envisages that authorized persons, i.e., port state control officers, are obliged to assess whether the ship is of an existing (required) standard with regard to safety, health, or the environment (Section 2 under Section 2.4, and Annex I) [48].

The Paris MoU stipulates the obligation of State Parties to perform inspections of any foreign ship of a certain priority, calling at port or anchorage of the MoU region [48,51-55]. Ship detention and arrest must be reduced to a minimum. In that sense, the primary objectives of the Paris MoU are to avoid multiple controls of the same ship navigating within the Paris MoU region within a certain period and to harmonize PSC in all ports covered by the Paris MoU in order to avoid the so-called "port shopping" - avoidance of ports with strict control and visiting of ports with milder control [56].

\subsection{Principles of Functioning}

The functioning of PSC within the Paris MoU region is organized, efficient, and consistent. The Paris MoU stipulates the procedure of ship inspection [48]. Under this Memorandum, inspection procedures comprise certain activities (phases) and have been regulated by different Sections of specific Annexes. In this sense, the following Annexes are particularly important: Annex 7 (Ship Risk Profile), Annex 8 (Inspection and Selection Scheme) and Annex 9 (Inspection Type and Clear Grounds).

The first step of ship inspection is determining the Ship Risk Profile (SRP), i.e., the performance of risk assessment. Determining or, more precisely, assigning a certain risk profile to a ship is performed by using certain factors (parameters) specified in the Paris MoU. All factors may be divided into two groups. The first group includes generic factors, such as the type of ship, age of ship, flag, recognized organization, and company. The second group includes historic factors, such as the results of previous inspections, existing deficiencies, information on detention, and the time interval between controls [48, 52,53,55]. All ships calling at a port or anchorage of a Party to the Paris MoU are assigned a ship risk profile in the information system THETIS [57], using the combination of the above factors. Under the provisions of the Paris MoU, all ships may be classified as Low Risk Ships (LRS), High Risk Ships (HRS), and Standard Risk Ships (SRS) $[48,52,53,55]$. It is worth noting that THETIS, based on the data from the Paris $\mathrm{MoU}$, determines a ship risk profile on a daily basis, so that port authorities immediately recognize (high risk) ships which should be paid special attention while performing PSC.

This information system performs selection of ships which undergo inspection based on the determined ship risk profile, in compliance with Annexes 8 and 9 of the MoU. The inspection and selection scheme determines the priority of inspections, frequency, scope, and type of inspections. The Paris MoU provides a selection scheme which determines the priority of inspections, level, category, and type of inspections (Table 1).

Table 1. Selection scheme for inspection of different ship risk profiles at different intervals (Point 10 of Annex 8) [44].

\begin{tabular}{clc}
\hline Priority & \multicolumn{1}{c}{ Level } & Category of Inspection \\
\hline \multirow{3}{*}{ I } & Overriding factor & Additional \\
\cline { 2 - 3 } Ship must be inspected & $\begin{array}{l}\text { HRS not inspected in last 6 months } \\
\text { SRS not inspected in last 12 months }\end{array}$ & \multirow{2}{*}{ Periodic } \\
& LRS not inspected in last 36 months & \\
II & HRS not inspected in last 5 months & \\
\cline { 2 - 3 } Ship may be inspected & Ship with unexpected factors & Additional \\
\cline { 2 - 3 } & SRS not inspected in last 10 months & \multirow{2}{*}{ Periodic } \\
& LRS not inspected in last 24 months & \\
\hline
\end{tabular}


The selection scheme has been designed so as to put an emphasis on the more frequent inspection of high risk ships, while low risk ships and standard risk ships undergo inspection in longer time intervals between inspections. While selecting ships, the first thing to do is to determine the priority of inspections, i.e., to determine the Priority (priority group) within which a ship falls. Ships may fall into Priority I or Priority II. If a ship has not been categorised within Priority I or Priority II, it is deemed that such a ship has no priority at all and, accordingly, will not undergo inspection, unless there are clear grounds for doing so $[48,52,53,55]$.

Inspection of ships falling within Priority I is obligatory, while inspection of ships falling within Priority II is not obligatory—-those ships may be inspected $[48,52,53,55]$.

The data on the ship risk profile, priority level, and previous inspections with an insight into deficiencies, are available to port authorities based on (from) the THETIS information system of the Paris Memorandum. These data condition the type of inspection to be carried out, marine areas where special attention should be paid, as well as the composition of the team of inspectors to perform an inspection.

Inspection types of foreign ships in the ports of the Paris MoU may be initial, more detailed, and expanded. After the completion of an inspection, the record of the inspection is kept following an appropriate template. The record includes the results of the inspection, identified deficiencies, as well as details on every measure undertaken. The inspector notifies the ship master of the contents of the record, as well as of all commitments resulting from the records for the ship master, ship owner, or other authorised person.

In the event that less severe deficiencies in the implementation of regulations have been identified during inspection, the inspector orders the ship master to rectify them within a given deadline. If the ship master fails to do so or the deficiency is such that it obviously endangers safety, health, or the environment, the inspector imposes the measure of prohibition of leaving the port or termination of the activity during which deficiencies have been identified [48,52]. The Paris MoU envisages the possibility that a ship concerned proceeds to the nearest appropriate repair yard available where deficiencies cannot be remedied in the port of inspection (Article 3.8) [48].

In case of detention, the competent authority of the port state where the ship has been inspected will immediately notify the flag administration and, where appropriate, the recognised organisation that has issued the relevant certificates on behalf of the flag Administration.

The possibility of banning ships which do not meet the prescribed standards from the Paris MoU region is particularly important [58]. Namely, the Parties have been recommended to ensure that a foreign merchant ship is refused access to its ports and anchorages in certain cases (Article 4) [48].

\section{Montenegro on the Path to Become a Paris MoU Member}

In order for a candidate state to become a full member of the Paris MoU, it should inevitably meet certain qualitative criteria (Annex 5) [48]. In addition to meeting the basic geographical criterion (Article 9 Section 9.2) [44], the maritime authority of the state may adhere as a full member provided that certain criteria have been met. Firstly, it should explicitly subscribe to the commitments under the Paris MoU and ratify all "relevant instruments" in force. Secondly, the state should have sufficient capacity, logistically and substantially, to appropriately enforce compliance with international maritime safety standards, as well as provisions and activities specified in the Paris MoU. "Sufficient capacity" means the employment of properly qualified persons, i.e., qualified PSCOs who will have the capacity to inspect foreign ships. The Paris MoU also envisages a negative criterion to be met by a candidate state: its flag must not appear in the list of detentions (exceeding the average detention percentage), as published in the annual report in any of three years immediately preceding its application for full membership. The other criteria relate to the commitments of a candidate country as of its effective date of membership. Namely, on the effective date of membership, the country is obliged to establish a connection to the information system THETIS and pay its share in the operating cost of the 
Memorandum based on the previously-signed Financial Agreement. The assessment of compliance with the above conditions of a candidate country will only be valid for each individual case.

In its endeavours to become integrated into the international maritime framework, Montenegro applied for membership of the Paris MoU in 2011. The primary task set by Montenegro was the improvement of safe maritime transport and environmental protection [59]. The same year, it became a cooperating member of the MoU, with the realistic possibility to become a full member in the future [60].

\subsection{Impediments and Success}

To assess the current state of play in the field of maritime affairs, the Monitoring Team of the Paris MoU visited the maritime authorities of Montenegro on several occasions. The Team provided certain recommendations, as well as objections, which should be particularly treated in order to meet the qualitative criteria.

The Report of the Fact-Finding Mission to the Maritime Authority of the Republic of Montenegro [53] states the following:

(a) Necessity of ratification of all "relevant instruments" and their implementation in the Montenegrin national legislation;

(b) Harmonisation of national legislation with provisions of the Paris MoU. Since it has been noted that the procedure of inspection of foreign ships in the ports of Montenegro, as well as the flow of procedures carried out by the Montenegrin port state control officers, is not compliant with provisions of $\mathrm{MoU}$, it has been recommended that the procedure under the MoU becomes implemented in its totality in the legal system of Montenegro.

(c) Setting up of an adequate institutional structure for the performance of the inspection of foreign ships, clearly defining the competencies, responsibilities, and roles of all entities involved in the inspection of foreign ships.

(d) The need for training and professional development of the maritime safety inspectors of Montenegro and the fulfilment of conditions in terms of their qualification pursuant to Annex 6 (Minimum Criteria for Port State Control Officers) of the Paris MoU has been particularly emphasised. One objection stated was that Montenegrin inspectors have not yet been fully familiarised with the contents of the Paris MoU manual, i.e., the PSC inspection guidelines.

A positive conclusion was that Montenegro undertook steps toward reducing the detention percentage of ships entitled to fly the flag of Montenegro, which is below the average detention of ships from the MoU region. It has been suggested that Montenegro continues with appropriate activities to that end. This can be considered as a success toward becoming a full member of the Paris MoU.

Following the above recommendations provided by the Paris MoU Monitoring Team (a, b, c, d), Montenegro updated the following steps:

(a) At present, Montenegro has all "relevant instruments" of the Paris MoU ratified. In addition to the ratification, the Parliament of Montenegro adopted the Law on Ratification of the Paris MoU on 31 July 2015 [37]. Accordingly, all relevant instruments, and the Paris MoU itself, became an integral part of the internal legal order of Montenegro.

(b) Taking into consideration the recommendations and objections provided by the Monitoring Team in terms of harmonisation of national legislation with the provisions of the Paris MoU, the maritime authorities of Montenegro very quickly became aware of deficiencies in the national legislation on PSC, as well as of the need to introduce changes in this field (see Section 4.2. for more detail).

(c) Institutional framework for the performance of PSC has been set up in Montenegro. The Harbour Master's Office in Bar and the Harbour Master's Office in Kotor are in charge of inspection operations in Montenegro (Article 183) [22]. The port state control officers of Montenegro perform inspections which, inter alia, include inspection of foreign ships calling at ports of Montenegro. 
(d) Speaking of the fulfilment of necessary requirements in terms of qualifications and professional development necessary for the performance of the inspection of foreign ships, it could be said that, at the moment, inspectors in Montenegro fully meet all requirements in formal terms, which could be evidenced by numerous awarded certificates. All requirements in terms of qualification of inspectors under the Paris MoU (Annex 6) [48] have been fully implemented in the Montenegrin legislation. Since 2011, when Montenegro applied for membership of the Paris $\mathrm{MoU}$, some funds have been allocated for training and professional development of Montenegrin inspectors despite generally limited funds. In this sense, their active participation in numerous seminars and workshops organised by the IMO, EMSA, and other organisations aimed at training and professional development of PSCOs is crucial. Additionally, in order to perform a safe and efficient inspection of foreign ships, Montenegrin inspectors possess all necessary protective and working equipment.

It is worth noting that an incomplete harmonisation of procedures for the performance of PSC, incomplete training and experience of PSCOs have also been observed in the states that are full members of the Paris MoU [61-64]. What has also been observed is a difference between full members in terms of availability of funds, as well as the lack of staff in specific member states. Additionally, PSCOs are subjective in terms of applying the procedure of ship detention, which results from differences in experience and training of PSCO. Therefore, we can rightfully say that Montenegro, as a cooperating member, is facing similar problems like some full members. This should not be understood as an excuse but, instead, as a challenge in the active action toward overcoming the mentioned problems and becoming a full member as soon as possible.

\subsection{Improved Legal Solutions Related to Inspection in Montenegro}

Given that the procedure of foreign ships control in the ports of Montenegro, as well as the very flow of procedures performed by the Montenegrin port state control officers (PSCOs), is not compliant with the provisions of the Paris $\mathrm{MoU}$, it has been recommended that the procedure under the MoU is fully transposed into the legal system of Montenegro. In this sense, it has been concluded that the national legislation should be subject to changes. It is advisable to first amend the Law on Maritime Navigation Safety from 2013 towards its compliance with the Paris MoU. Subsequently, it is necessary to adopt a new Rulebook on PSC which is to be fully compliant with the provisions of the Paris MoU.

The basic act under which the Montenegrin PSCOs control foreign ships calling at the ports of Montenegro is entitled the Rulebook on Special Conditions to be Fulfilled by Maritime Navigation Safety Inspectors and the Procedure of Performance of Inspection from 2015 [65]. A detailed analysis of the Rulebook discloses numerous deficiencies. In terms of its formal structure, it is observable that the Articles are not linked in a systematic way, which makes its implementation difficult. The Rulebook contains certain terms, while it does not provide the meaning (explanation) of the terms. The definition of certain terms is omitted or inadequate. The flow of procedures, i.e., the procedure of inspection performance, has not been clearly specified. Additionally, numerous provisions on the performance of the PSC from the Paris MoU have not been properly interpreted, such as provisions on the criterion and selection of ships which undergo inspection, annual obligations of inspection, and the manner of fulfilment of an annual obligation of inspection, delay and failure of inspection, priority groups, etc. Taking all this into consideration, it was unreasonable to expect that the port state controls in the ports of Montenegro would be performed in compliance with the provisions of the Paris MoU. Why did the maritime authorities of Montenegro make such an omission and adopt the Rulebook which was not compliant with the provisions of the Paris MoU? Certainly, the basic reasons should be traced in the lack of maritime-law specialists, on one hand, and the absence of consultations between the Ministry of Transportation and Maritime Affairs of Montenegro and the maritime management bodies, on the other.

In the context of the above, the maritime administration of Montenegro undertook certain activities. The amendments to the Law on Maritime Navigation Safety, with improved solutions 
in the field of inspection of foreign ships and undertaking of corrective measures toward remedying of deficiencies in PSC, were adopted in October 2017. The new Rulebook on the Procedure of Ship Inspection and the Design of Identity Cards of Inspectors [66] was adopted in March 2018.

The Rulebook comprises 26 articles, 14 templates, and six annexes. The Rulebook contains the detailed provisions on the following: manner, procedure, and frequency of inspections of foreign ships in the ports and anchorages of Montenegro; criteria and procedure of ship selection; measures undertaken by PSCOs after the performance of an inspection; and acting under complaints. These provisions have been fully harmonised with the Paris MoU. It is reasonable to expect that the adoption of the Rulebook and consistent implementation of its provisions in practice by the Montenegrin PSCOs will make the control of foreign ships in the ports of Montenegro become identically performed as in the other ports of the states of the Paris MoU region. This is an important step forward that Montenegro made toward becoming a full member of the Paris MoU.

\section{Conclusions}

The regional PSC keeps strengthening in terms of ensuring safety at sea and marine ecosystem protection. In our endeavors to show the necessity of strengthening the PSC of Montenegro, in this work we provided an overview of the relevant legislation and efforts toward the accession of Montenegro to the Paris Memorandum. The full membership of the Paris Memorandum would bind Montenegro to act on an equal footing with other members toward the elimination of substandard ships and the reduction of maritime accidents which result in casualties, loss of property, and/or pollution of the marine environment. In this sense, Montenegro should be fully responsible, both as a flag country and a port country, for its own actions in the circle of responsibility of all participants in the transport chain under the "port to port" principle.

On this path, Montenegro has succeeded so far in terms of decreasing the detention percentage of ships entitled to fly the flag of Montenegro, ratification of all relevant instruments of the Paris MoU, general harmonization of the Montenegrin legislation on PSC with the requirements of the Paris MoU, and the establishment of an adequate institutional framework for the performance of the PSC where the Montenegrin PSCOs play a dominant role.

What has been identified as an impediment on this path is the necessity to improve the standard of performance of PSC inspections through continuous training of Montenegrin inspectors in compliance with MoU, provision of adequate equipment for inspection performance, and non-restrictive access to the THETIS database. In addition, it is necessary to further harmonise national legislation on PSC. In this sense, it is necessary to adopt a new Rulebook on PSC where the solutions from the Paris MoU would be fully transposed, which would result in the performance of PSC in compliance with international standards. The reasons for such a situation should certainly be traced among the lack of administrative capacities, poor vertical communication between the line Ministry of the Government and maritime administration, a poorly-defined strategy of maritime development, non-existence of an environmental protection strategy, a lack of funds, etc. All this, and much more, characterizes the transition conditions in which Montenegro functions, permanently facing the recurrence of economic crises and slow development.

Future activities should be oriented toward the monitoring of achieved improvements of Montenegro in the field of PSC, as well as toward the monitoring of the dynamics of improvement of regional and international standards on the supervision of sea activities. With a global approach to PSC, it is clear that Montenegro needs to cooperate with the members of the Paris Memorandum more intensely and closely in order to ensure a sustainable and responsible shipping industry and marine ecosystem protection on regional and global scales.

Conflicts of Interest: The author declares no conflicts of interest. 


\section{References and Notes}

1. IMO. IMO and the Environment. International Maritime Organization, 2011. Available online: http://www. imo.org/en/OurWork/Environment/Documents/IMO\%20and\%20the\%20Environment\%202011.pdf (accessed on 10 December 2017).

2. Oregon State University. Marine Studies Initiative, 10-Year Strategic Plan. 2016-2025. Available online: http:/ / sites.oregonstate.edu/oversize-uploads/MSI\%20Strategic\%20Plan_FINAL_high-v2.pdf (accessed on 13 December 2017).

3. Vokić Žužul, M.; Bulum, B. Pravo mora u Sredozemlju tijekom povijesti. Misc. Hadriat. Mediterr. 2017, 4, 47-80. [CrossRef]

4. Jin, D.; Kite-Powell, H.L.; Talley, W.K. U.S. ship accident research. In Maritime Safety, Security and Piracy; Informa LLP: London, UK, 2008; pp. 55-71.

5. Lister, J. Green Shipping: Governing Sustainable Maritime Transport. Glob. Policy 2015, 6, 118-127. [CrossRef]

6. Geng, X.; Wen, Y.; Zhou, C.; Xiao, C. Establishment of the sustainable ecosystem for the regional shipping industry based on system dynamics sustainability. Sustainability 2017, 9, 742. [CrossRef]

7. Lim, K. The Role of the International Maritime Organization in preventing the pollution of the world's oceans from ships and shipping. UN Chron. 2017, 54, 52-54. [CrossRef]

8. Bender, K. Encyzlopedia Princetoniensis, Liechtenstein Institute on Self-Determination Bendheim Hall, Princeton. Available online: https:/ / pesd.princeton.edu/?q=node/239 (accessed on 15 January 2018).

9. Vukčević, M.; Bošković, M. Judicial System in Montenegro (Historical Development, Basic Principles, and Organisaton). Law Justice Rev. 2016, 7, 1-26.

10. Jovanović, N. Serbia and Montenegro-Transport Law, International Encyclopaedia for Transport Law; Kluwer Law International BV: Alphen Aan Den Rijn, The Netherlands, 2005; p. 27.

11. Triva, S. Law on Maritime and Inland Navigation with Notes and Comments; Official Gazette: Zagreb, Croatia, 1981; pp. 11-19.

12. Ivošević, B.; Pejović, Č. Development of marine navigation in the FR Yugoslavia and Montenegro and maritime navigation. Law J. Mag. Law Theory Pract. 1996, 1-2, 17-42.

13. Law on Maritime and Inland Navigation. Official Gazette of the Federal Republic of Yugoslavia 12/1998, 1998.

14. Decision Promulgating Independence of Montenegro. Official Gazette of the Republic of Montenegro 36/2006, 2006.

15. Mudrić, M. Croatia-Croatia Maritime Law: General Introduction and Examination of Legislation, Jurisprudence and Recent Bibliography. Anu. Derecho Marit. 2012, 29, 309-322.

16. Pavliha, M.; Grbec, M. Maritime Law, Jurisprudence and the Implementation of International Conventions into the Legal System of the Republic of Slovenia. Il Diritto Marittimo. 2001; pp. 1-11. Available online: http:/ / www.dpps-mlas.si/pdf/MARITIME\%20LAW,\%20JURISPRUDENCE\%20AND\% 20THE\%20IMPLEMENTATION\%20-\%20IL\%20DIRITTO\%20MARITIMO.pdf (accessed on 12 January 2018).

17. Law of the Sea ("Official Gazette of the Republic of Montenegro", Nos. 17/07 of 31 December 2007, 6/08 of 25 January 2008, 40/11 of 8 August 2011).

18. Law on Yachts ("Official Gazette of the Republic of Montenegro", No. 46/07 of 31 July 2007).

19. Law on Ports (“Official Gazette of the Republic of Montenegro", Nos. 51/08 of 22 August 2008, 40/11 of 08 August 2011, 27/13 of 11 June 2013).

20. Law on Marine Fisheries and Mariculture ("Official Gazette of the Republic of Montenegro", No. 56/09 of 14 August 2009).

21. Law on the Prevention of Sea Pollution from Vessels ("Official Gazette of Montenegro", Nos. 20/11 of 15 April 2011, 27/14 of 30 June 2014).

22. Law on Maritime Navigation Safety (“Official Gazette of Montenegro” Nos. 62/13 of 31 December 2013, 06/14 of 4 February 2014, 47/15 of 18 August 2015, 71/17 of 31 October 2017).

23. Law on Security Protection of Ships and Ports ("Official Gazette of the Republic of Montenegro" No. 53/16 of 11 August 2016).

24. National Plan for Emergent Reaction in the Event of Sea Pollution from Vessels; Maritime Safety Department of Montenegro, Ministry of Transport and Maritime Affairs of Montenegro: Podgorica, Montenegro, 2011. 
25. Law on Environment (“Official Gazette of Montenegro" Nos. 48/08 of 11 August 2008, 40/10 of 22 July 2010, 40/11 of 8 August 2011, 27/14 of 30 June 2014).

26. Law on Fundamentals of Environmental Protection ("Official Gazette of the Federal Republic of Yugoslavia" No. 24/98 of 15 March 1998).

27. Law on Environment ("Official Gazette of the Republic of Montenegro" No. 12/96 of 16 April 1996).

28. Law on Nature Protection ("Official Gazette of the Socialist Republic of Montenegro" No. 36/77 of 19 December 1997, 2/89 of 8 February 1989).

29. Law on Environment (“Official Gazette of Montenegro" No. 52/16 of 9 August 2016).

30. Constitution of Montenegro ("Official Gazette of Montenegro" No. 1/07 of 25 October 2007).

31. IMO. Status of IMO Treaties. International Maritime Organization, 2018. Available online: http:/ / www. imo.org/en/About/Conventions/StatusOfConventions/Documents/Status\%20-\%202018.pdf (accessed on 5 January 2018).

32. Ćorić, D. Sea Pollution from Vessels, International and National Legislation; Faculty of Law of the University of Rijeka: Rijeka, Croatia, 2009; p. 56.

33. Emecen Kara, E.G.; Oksas, O. Evaluation of Maritime Safety in Istanbul Strait using Port State Control Inspections. In Proceedings of the International Conference on Engineering and Natural Sciences (ICENS), Skopje, Macedonia, 15 May-19 June 2015.

34. Emecen, E.G.; Yıldız, M. Limanlarımızda Liman Devleti Kontrolü Uygulamaları. In Türkiyenin Kıyı ve Deniz Alanları VI; Ulusal Konferans: Mugla, Turkey, 2006.

35. Özçayır, O.Z. Port State Control; LLP Professional Publishing: London, UK, 2001.

36. Emecen Kara, E.G. Risk Assessment in the Istanbul Strait Using Black Sea MOU Port State Control Inspections. Sustainability 2016, 8, 390. [CrossRef]

37. Law on Ratification of the Paris Memorandum of Understanding on Port State Control ("Official Gazette of Montenegro-International Treaties", No. 10/2015 of 21 August 2015).

38. IMO. Resolution A.1052 (27); Procedures for Port State Control. 2011. Available online: https://www. classnk.or.jp/hp/pdf/activities/statutory/ism/imo/A.1052(27).pdf (accessed on 10 December 2017).

39. Li, K.X.; Zheng, H. Enforcement of law by the Port State Control (PSC). Marit. Policy Manag. 2008, 35, 61-71. [CrossRef]

40. Lappalainen, J. Finnish Maritime Personnel's Conceptions on Safety Management and Safety Culture; Turun yliopisto University of Turku: Turku, Finland, 2016; p. 24.

41. Özçayır, O.Z. The Use of Port State Control in Maritime Industry and the Application of the Paris MOU. Ocean Coast. Law J. 2009, 14, 209.

42. Xu, S. Port State Control: Review and Assessment. Master's Thesis, World Maritime University, Malmö, Sweden, 2001; p. 7.

43. Knapp, S.; Franses, P.H. Comprehensive Review of the Maritime Safety Regimes. Econ. Inst. Res. Pap. 2007, 30, 241-270.

44. Silos, J.M.; Piniella, F.; Monedero, J.; Walliser, J. The Role of the Classification Societies in the Era of Globalization: A Case Study. Marit. Policy Manag. 2013, 40, 384-400. [CrossRef]

45. Emecen, E.G.; Karaoglu, M. Liman Devleti Kontrolü Incelemeleri ve Risk De gerlendirmesi. In Türkiyénin Kıyı ve Deniz Alanları VIII; Ulusal Konferansı: Ankara, Turkey, 2008.

46. Paris MoU on PSC. Safeguarding Responsible and Sustainable Shipping, Third Joint Ministerial Conference. Available online: https://www.parismou.org/global-leaders-sign-new-international-declaration-shipsafety-3rd-joint-ministerial-conference-0 (accessed on 1 January 2018).

47. Paris MoU on PSC. Safe and Sustainable from Port to Port, Third Joint Ministerial Conference. Available online: https://www.parismou.org/global-leaders-sign-new-international-declaration-shipsafety-3rd-joint-ministerial-conference-0 (accessed on 1 January 2018).

48. Paris MoU. Paris Memorandum of Port State Control 40th Amendment; Secretariat Paris MoU on PSC: The Hague, The Netherlands, 2017.

49. Molenaar, E. Coastal State Jurisdiction over Vessel' Source Pollution; Kluwer Law International: The Hague, The Netherlands, 1998; p. 125.

50. Bang, H.S. Is port state control an effective means to combat vessel-source pollution? An empirical survey of the practical exercise by port states of their powers of control. Int. J. Mar. Coast. Law 2008, 23, 727. [CrossRef] 
51. Rodríguez, E.; Piniella, F. The New Inspection Regime of the Paris Mou on Port State Control: Improvement of the System. J. Marit. Res. 2012, 9, 9-16.

52. The New Inspection Regime (NIR) of the Paris Memorandum of Understanding (PMoU). Available online: https:/ / www.deutsche-flagge.de/de/redaktion/dokumente/dokumente-sonstige/thenew-inspection-regime.pdf (accessed on 5 February 2018).

53. Schiferli, R.W.J. Introduction of a New Inspection Regime, General Secretary. 2011. Available online: https: / / www.intertanko.com/upload/Richard\%20Schiferli.pdf (accessed on 9 February 2018).

54. Port State Control. On Course for Safer Shipping; Annual Report; Paris MoU: Paris, France, 2011; p. 5.

55. BIMCO. The New Inspection Regime of the Paris MoU. Available online: http://www.lesiagroup.com/ Resources/BIMCO\%20NIR\%20Guide.pdf (accessed on 13 February 2018).

56. Bang, H.S.; Jang, D.J. Recent Developments in Regional Memorandums of Understanding on Port State Control. Ocean Dev. Int. Law 2012, 43, 170-187. [CrossRef]

57. European Maritime Safety Agency. THETIS. Available online: http://emsa.europa.eu/psc-main/thetis.html (accessed on 15 February 2018).

58. Cariou, P.; Wolff, F.C. Identifying substandard vessels through Port State Control inspections: A new methodology for Concentrated Inspection Campaigns. Mar. Policy 2015, 60, 27-39. [CrossRef]

59. Transport Development Strategy of Montenegro; Government of Montenegro, Ministry of Transport and Maritime Affairs: Podgorica, Montenegro, 2008. Available online: http:/ /webcache.googleusercontent.com/ search?q=cache:eQIJ5j3nWF8J:www.seetoint.org / seetodocuments $/ 1264+\& c d=2 \& \mathrm{hl}=\mathrm{en} \& \mathrm{ct}=\mathrm{clnk} \& \mathrm{gl}=\mathrm{me}$ (accessed on 1 January 2017).

60. Port State Control. Taking Port State Control to the Next Level; Annual Report 2012; Paris MoU: Paris, France, 2012; p. 17.

61. Report of the Fact-Finding Mission to the Maritime Authority of the Republic of Montenegro; Ministry of Transport and Maritime Affairs of Montenegro: Podgorica, Montenegro, 2016; pp. 1-15.

62. Graziano, A.; Schröder-Hinrichs, J.U.; Ölcer, A.I. After 40 years of regional and coordinated ship safety inspections: Destination reached or new point of departure? Ocean Eng. 2017, 143, 217-226. [CrossRef]

63. Knapp, S.; Van de Velden, M. Visualization of differences in treatment of safety inspections across Port State Control regimes: A case for increased harmonization efforts. Transp. Rev. 2009, 29, 499-514. [CrossRef]

64. Knudsen, O.F.; Hassler, B. IMO legislation and its implementation: Accident risk, vessel deficiencies and national administrative practices. Mar. Policy 2011, 35, 201-207. [CrossRef]

65. Rulebook on Special Conditions to be fulfilled by Maritime Navigation Safety Inspectors and the Procedure of Performance of Inspection ("Official Gazette of Montenegro" No. 22/2015 of 4 May 2015).

66. Rulebook on the Procedure of Ship Inspection and the Design of Identity Cards of Inspectors (“Official Gazette of Montenegro" No. 14/2018 of 5 March 2018). 